\title{
癌免疫療法臨床試験＼cjkstart最近の話題
}

\author{
猪爪隆史
}

\section{Recent clinical trials of tumor immunotherapy}

\author{
Takashi INOZUME \\ University of Yamanashi, Department of Dermatology
}

(Accepted March 19, 2013)

\begin{abstract}
summary
Many recent clinical trials of immunotherapy for advanced tumors have reported remarkable results. For example, blockade of cytotoxic T-lymphocyte antigen 4 (CTLA-4) significantly improved median overall survival of melanoma patients. Blockade of programmed cell death 1 (PD-1) or programmed cell death 1 ligand 1 (PD-L1) induced durable tumor regression and prolonged disease stabilization in patients with advanced cancers, including melanoma, non-small-cell lung cancer, and renal cell cancer. In addition, adoptive cell transfer of tumor infiltrating lymphocytes (TILs) and T cells transduced with high avidity T cell receptor (TCR) genes have been reported to elicit marked durable tumor regression in melanoma patients. Further, clinical trials of cancer vaccines targeting various tumors have been conducted to prolong overall survival. In this review, some remarkable results achieved in recent clinical trials are summarized.
\end{abstract}

Key words_ tumor immunology; CTLA-4; PD-1; TIL; tumor vaccine

抄 録

近年，多くの癌免疫療法の臨床試験が各所で行われている. 方法，対象患者，目的も多様化してきており，特に ここ数年，良好な成果の報告が相次いでいる．T cell 機能抑制分子である cytotoxic T-lymphocyte antigen 4 （CTLA-4）に対する阻害抗体は進行期メラノーマ患者の全生存率を延長し，さらに一部の患者には長期寛解をも たらすことが示された。同様に programmed cell death 1 (PD-1) や programmed cell death 1 ligand 1 (PD-L1) に 対する阻害抗体も一部のメラノーマ, 非小細胞肺癌, 腎細胞癌を長期にわたり縮小させることが分かった。 また, 切除されたメラノーマ腫瘍から培養した腫瘍浸潤リンパ球 (tumor infiltrating lymphocyte, TIL) や, 腫瘍特異的 $\mathrm{T}$ 細胞受容体の遺伝子を導入した人工 $\mathrm{T}$ cell を用いた養子免疫療法では，少ない症例数ながらメラノーマと滑膜肉 腫に挍いて劇的な奏効例と長期寛解例が報告されている，一方で癌ワクチン療法では簡便で体への負担が少ない特 性を生かし，他の治療との併用も含めてより多くの癌患者を対象とした大規模な臨床試験が行われている．本稿で は最近の癌免疫療法の臨床試験において顕著な成果を挙げているものをいくつか紹介する．こうした臨床試験にお ける奏効例の特性を解析し次の臨床試験に反映させていくことで, 癌免疫療法の効果がより確実になっていくもの と期待される.

\section{はじめに}

癌免疫学の基礎研究の発展に伴い，その成果に基 づた臨床試験が数多く行われている. 現状におい て大半は開発途上にあるが，症例数を重ねるにつれ て一部の治療（大量 IL-2, 抗 CTLA-4 抗体, 抗 PD-1 抗体, TIL 療法, $\mathrm{T}$ 細胞受容体遺伝子療法な ど）では一部の進行期癌患者に長期完全寛解（う治 瘉）をもたらすことが分かってきた。この総説では

山梨大学皮膚科学教室
最近の癌免疫療法臨床試験のなかで, 現時点におい て顕著な抗腫瘍効果が報告されているものをいくつ か紹介する.

\section{I. 非特異的 T cell 活性化物質の投与}

癌に対する免疫反応において重要な役割を果たす のは T cell (CTL, helper T cell) であることが長年 の基礎研究で明らかにされている. T cellにはアク セル分子とブレーキ分子が多数存在し，多様な状況 下での免疫反応を緻密にコントロールしている11. 現在までに同定されている $\mathrm{T}$ cell のブレーキ分子の 
代表的なものとして CTLA-4 および PD-1 が挙げら れ，いずれもそのシグナルは $\mathrm{T}$ cell の増殖抑制，サ イトカイン産生低下，アポトーシス誘導などを惹起 する1). CTLA-4 にシグナルを入れるリガンドは主 に抗原提示細胞上に発現される CD80 や CD86, PD-1のリガンドは主に腫瘍や抗原提示細胞に発現 される PD-L1 である. 最近 CTLA-4 に対する阻害 抗体 (CTLA-4 にシグナルが入るのを遮断する抗体) の単独投与が進行期メラノーマ患者の全生存率を延 長し，一部の患者に長期完全寛解をもたらすことが 相次いで報告され話題となった ${ }^{2 \sim 4)}$. 同様に PD-1， あるいはそのリガンドである PD-L1 に対す る阻害抗体の臨床試験では, メラノーマおよび非小 細胞肺がん, 腎蔵がんなどにおいて投与群の約 1-2 割に腫瘍縮小効果を認め, その responder の約半数 において腫瘍縮小効果が 1 年以上持続した ${ }^{5,6}$ ）（表 1). 一つの分子に対する阻害抗体の単独投与がメラ ノーマをはじめとする複数の癌に効果を示したのは 驚くべき結果ある．そして抗腫瘍効果とともに自己 免疫現象上考元られる有害事象（大腸炎, 皮膚炎, 肝炎, 下垂体炎, 白班) の発生が報告されているこ とは，これらによる抗腫瘍効果が患者生体内で癌に 対する免疫反応が惹起, 増強された結果であること を示唆している．CTLA-4 や PD-1 などの免疫寛容 を維持するために重要な $\mathrm{T}$ cell 機能抑制分子群を “immune-checkpoint”と呼ぶこともあり1)，より有 効な抗腫瘍免疫を惹起するためには“immunecheckpoint”のうちどの分子をどのように阻害すべ きかといった今後の検討が必要であろう. また現在 これらの抗体を他の治療と組久合わせて, 上り効果 の高い治療法の開発が進められている.

$\mathrm{T}$ cell のブレーキ分子に対する阻害抗体投与の他 に, 非特異的な $\mathrm{T}$ cell 活性化による免疫療法の成功 例として大量 IL-2 療法が挙げられる7)。これは 1 回 72 万 IU/kg の IL-2 を 8 時間毎に静注（重篤な 副作用が出れば中断), 最大で計 15 回投与して 1 サ イクルとし，10-15 日間の休薬後，さらに 1 サイク ル繰り返して，1コースとする方法である. 米国国 立癌研究所外科で行われた, 進行期メラノーマ 182 例抢よび腎臓癌 227 例に対する大量 IL-2 療法の臨 床試験の報告によると, 奏効率はメラノーマで 15 $\%$, 腎臓癌で 19\%, そのうち完全寬解（CR）はメ ラノーマで7\%, 腎臓癌で 9\%であった。この報告 で興味深いのは完全寛解（CR）に至った患者 33 例 の約 9 割が 20 年近くにわたって長期生存している ことである.この傾向は抗 CTLA-4 抗体療法を受 け完全寬解に至った進行期メラノーマ患者にもみら れる4 ${ }^{4}$. 少数ながら，こうした長期完全寛解（う治 癒）に至る患者が存在することは, 癌に対する免疫 療法の有効性を強く示唆している.

表 1 最近の癌免疫療法 臨床試験の成功例

\begin{tabular}{|c|c|c|c|}
\hline プロトコル & 対象患者（人数） & 特 記 事 項 & 文献 \\
\hline $\begin{array}{l}\text { 抗がん剂単独 vs 抗 CTLA-4 抗 } \\
\text { 体併用（Phase III） }\end{array}$ & $\begin{array}{c}\text { 進行期メラノーマ } \\
502 \text { 例 }\end{array}$ & $\begin{array}{l}\text { 生存期間中央值 } \\
\text { 抗がん剂単独で } 9.1 \text { ヶ月 } \\
\text { 抗 CTLA-4 抗体併用で } 11.2 \text { ヶ月 }\end{array}$ & 3 \\
\hline $\begin{array}{l}\text { ペプチド単独 vs 抗 CTLA-4 抗 } \\
\text { 体併用 or 単独（Phase III） }\end{array}$ & $\begin{array}{c}\text { 進行期メラノーマ } \\
676 \text { 例 }\end{array}$ & $\begin{array}{l}\text { 生存期間中央値 } \\
\text { ペプチド単独で } 6.4 \text { ヶ月 } \\
\text { 抗 CTLA-4 抗体使用群は約 } 10 \text { ヶ月 }\end{array}$ & 2 \\
\hline 抗 PD-1 抗体単独（Phase I/II） & $\begin{array}{l}\text { 各種進行期癌 } \\
207 \text { 例 }\end{array}$ & $\begin{array}{l}\text { メラノーマで奏効率 } 28 \% \text {, 非小細胞肺がんで } 18 \% \text {, 腎臓がん } \\
\text { で } 27 \% \text {. Responder } 96 \text { 割は奏効状態が } 1 \text { 年以上持続. 組織 } \\
\text { でのPD-L1 発現と効果に関連あり. }\end{array}$ & 5 \\
\hline $\begin{array}{l}\text { 抗 PD-L1 抗体単独 } \\
(\text { Phase I/II) }\end{array}$ & $\begin{array}{l}\text { 各種進行期癌 } \\
296 \text { 例 }\end{array}$ & $\begin{array}{l}\text { メラノーマで奏効率 } 17 \%, \text { 非小細胞肺がんで } 10 \%, \text { 腎臓がん } \\
\text { で } 12 \% \text {, 卵巣がんで } 6 \% \text {. Responder の } 5 \text { 割は奏効状態が } 1 \text { 年 } \\
\text { 以上持続. }\end{array}$ & 6 \\
\hline $\begin{array}{l}\text { プラセボ vs Sipuleucel-T } \\
\text { (Phase III) }\end{array}$ & $\begin{array}{l}\text { ホルモン療法抵抗性 } \\
\text { 進行期前立腺癌 } \\
512 \text { 例 }\end{array}$ & $\begin{array}{l}\text { Sipuleucel-T は患者末梢血単核球を前立腺癌抗原蛋白と GM- } \\
\mathrm{CSF} \text { で刺激したもの. 生存期間中央值がプラセボ } 21.7 \text { ケと } \\
\text { 比較して } 25.8 \text { ヶに延長 }\end{array}$ & 14 \\
\hline $\begin{array}{l}\text { 大量 IL-2 単独 vs 大量 IL-2+ペ } \\
\text { プチドワクチン（Phase III） }\end{array}$ & $\begin{array}{c}\text { 進行期メラノーマ } \\
185 \text { 例 }\end{array}$ & $\begin{array}{l}\text { 生存期間中央值は大量 IL-2 群 } 11.1 \text { ヶ月と比較して, peptide } \\
\text { 併用群で } 17.8 \text { ヶ 月に延長, 奏効率は } 6 \% \text { から } 16 \% \text { に改善. }\end{array}$ & 16 \\
\hline
\end{tabular}




\section{II. 養子免疫療法}

患者体内から採取した細胞をもとにして，直接の 抗腫瘍活性をもつ細胞を生体外で十分に増殖，活性 化し，患者体内に移入する治療を指す。 LAK (Lymphokine activated killer cells) に始まり，NK cell, ガンマデルタ $\mathrm{T}$ cell, 腫瘍特異的 $\mathrm{T}$ cell ク ローン, TIL (Tumor infiltrating lymphocytes), T cell 受容体遺伝子導入 $\mathrm{T}$ cell などの移入が行われて いるが，現状で比較的高い治療効果が報告されてい るのは米国国立癌研究所外科を中心に進められてい る, 進行期メラノーマに対する TIL 療法と T cell 受容体遺伝子導入 $\mathrm{T}$ cell 療法（表 2) である ${ }^{8 \sim 10}$ ).

TIL 療法は切除した転移組織から浸潤しているリン パ球を in vitroで大量に増殖させ, 大量 IL-2 とと もに免疫抑制状態にした患者に投与する，という治 療法である.93 例の進行期メラノーマを対象とし た臨床試験の報告では奏効率 56\%で完全寛解 (CR)

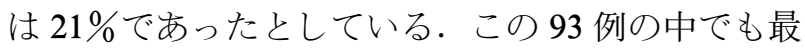
新の 25 例に限って見れば奏効率 $72 \%$, 完全寬解 (CR) $40 \%$ という驚異的な数字が記載されている. さらに驚くべきことに完全寬解に至った 19/20 例は 現在までのフォローで 4-7 年持続する長期完全寛解 であった（図 1A, B). TIL 療法は他の免疫療法之 比較すると一見複雑であるが，これまでに明らかに されている腫瘍免疫の問題点を克服するためには非 常に理にかなった治療法である。つまり腫瘍周囲に は抗腫瘍活性を持つ T cell が浸潤しているが，様々

表 2 米国国立癌研究所外科で実施された進行期メラノーマ に対する細胞移入療法の奏効率（文献 9 を改変） TIL 療法

\begin{tabular}{|c|c|c|c|}
\hline Protocol & $\begin{array}{c}\mathrm{CR} \\
\text { (完全寛解)*** }\end{array}$ & PR & $\begin{array}{c}\mathrm{OR} \\
(\mathrm{CR}+\mathrm{PR})\end{array}$ \\
\hline NMA* & $5 / 43$ & $16 / 43$ & $21 / 43(48 \%)$ \\
\hline 200 cGy TBI** & $5 / 25$ & $8 / 25$ & $13 / 25(52 \%)$ \\
\hline 1200 cGy TBI & $10 / 25$ & $8 / 25$ & $18 / 25(72 \%)$ \\
\hline
\end{tabular}

* NMA ; 化学療法のみによる前処置

** TBI; 化学療法と全身放射線照射による前処置

*** CR のほぼすべては現在も維持されている

TCR 受容体遺伝子治療

\begin{tabular}{|c|c|c|c|}
\hline TCR (Target Ag) & $\mathrm{CR}$ & PR & $\begin{array}{c}\mathrm{OR} \\
(\mathrm{CR}+\mathrm{PR})\end{array}$ \\
\hline F5 (MART-1)* & $0 / 20$ & $6 / 20$ & $6 / 20(30 \%)$ \\
\hline $154(\mathrm{gp} \mathrm{100})^{* *}$ & $0 / 19$ & $3 / 19$ & $3 / 19(18 \%)$ \\
\hline $3 \mathrm{H} 10(\mathrm{NY}-\mathrm{ESO}-1)^{* * *}$ & $2 / 11$ & $3 / 11$ & $5 / 11(52 \%)$ \\
\hline
\end{tabular}

* ヒ上由来 TCR 遺伝子 $* * *$ CDR3 改変高親和性 TCR 遺伝子

** HLA-A2 トランスジェニックマウス由来 TCR 遺伝子
な免疫抑制機構により十分に力を発揮出来ず，その ため腫瘍は増大し続けている。そこで腫瘍浸潤 T cell を生体外に取り出して抑制因子のない適切な条 件で増殖，活性化させ，さらにその T cell が十分に 力を発揮出来るよう生体の状況を整えてから戻すと いう発想である。しかしながら現状の TIL 療法は 治療法として普及するためには問題点が多く, ごく 限られた施設でしか実施出来ていない。切除組織か ら TIL を増殖させるには技術と経験を要する。 た TIL はへテロな $\mathrm{T}$ 細胞集団であるが，腫瘍拒絶 に重要な分画の認識抗原，フェノタイプなぞが十分 に分かっていない。したがって経験的に一度の治療 で $10^{11}$ 個という大量の $\mathrm{T}$ cell を投与する必要があ るため, 培養には長い時間(約 1 ヶ月から 1 ヶ月半) と膨大なコストを要する。さらに移入した TILを 効率よく患者生体に生着させるため, 白血病に対す る骨髄移植の際の前処置と同様の免疫抑制をかけ,

A

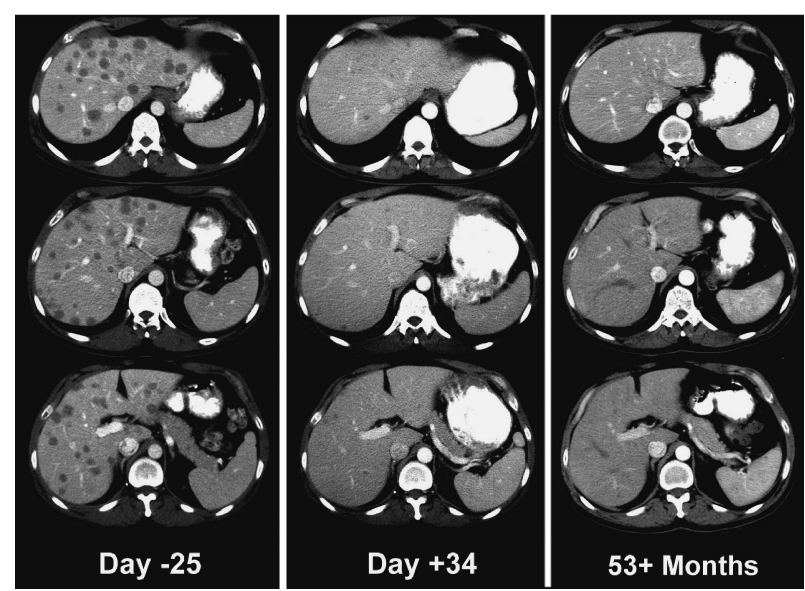

B

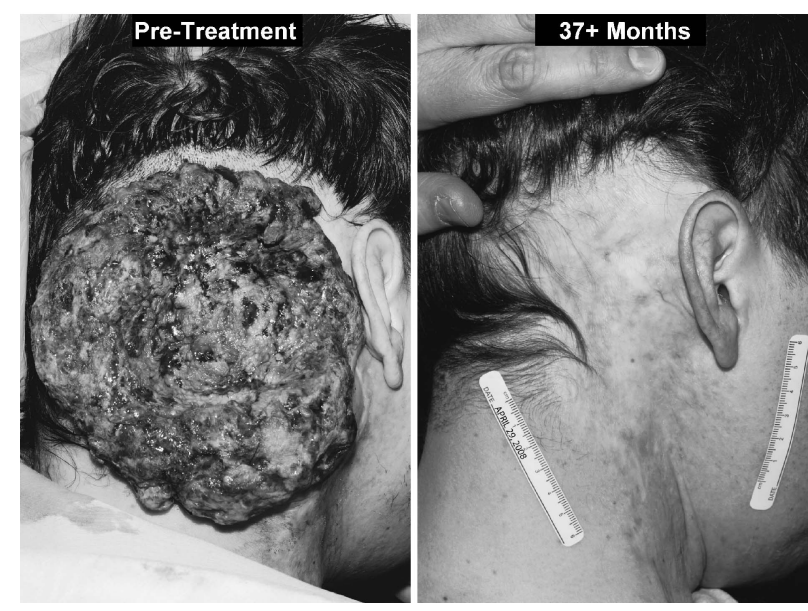

図 1 Tumor infiltrating lymphocyte (TIL) 療法により長期 完全寛解に至った進行期メラノーマ患者の例. 化学療 法や放射線療法に抵抗性の巨大皮膚転移や多発肝転移 が TIL 投与後に消失し, 奏効状態が 3 年以上にわたり 維持されている.（文献 8 より） 
大量の IL-2 とともに投与する（前処置と大量の IL-2 のみでは腫瘍縮小効果は認められないこと は, 同じ条件下で TIL 以外の細胞を移入する臨床 試験で明らかになっている)。そのため, 甚大な副 作用が起きた場合にそれを管理する施設やマンパ ワーなども必要である。これらの問題点を解決する 方法の一つとして, 切除直後の TIL から治療に有 用と思われる分画を同定するバイオマーカーの解析 が進められている。こうしたマーカーによって腫瘍 に強く反応し, 生体内で増殖, 生着しやすい分画だ けを培養前に抽出し, 効率よく増殖させることで, TIL 療法の簡便化, 普及が進むものと期待される ${ }^{11}$.

前述の他に，TIL を増殖させることができないメ ラノーマ患者が存在すること, 腫瘍に強く反応する TIL を増殖させるのはメラノーマ以外の癌では難し いこと, なども TIL 療法の大きな問題点である. これを解決するために開発されたのが，T cell 受容 体遺伝子導入 $\mathrm{T}$ cell を用いた養子免疫療法である.

これは刺激した患者末梢血単核球に，HLA-癌抗原 ペプチド複合体を認識する $\mathrm{T}$ cell 受容体遺伝子をレ トロウイルスベクターにより導入することで腫瘍特 異的 CTL を人工的に作製し，TIL と同じ要領で患 者体内に移入する方法である. 最近行われた,

HLA-A*0201 拘束性に NY-ESO-I という癌精巣抗 原（様々な癌と精巣のみに発現される抗原）を認識 する $\mathrm{T}$ cell 受容体遺伝子を用いた臨床試験では（メ ラノーマ 11 例, 滑膜肉腫 6 例）奏効率はそれぞれ 約 50\%（メラノーマの 2 例は完全寬解）であった. 特に滑膜肉腫に奏効したことは，適切な標的抗原を 選んで適切な $\mathrm{T}$ cell を移入すれば，すべての癌がこ の方法で治療可能であることを示唆する意義深い結 果である.しかしこちらも課題は多く，技術的な問 題, HLA 拘束性の問題, そしてなにより適切な標 的抗原の選択の問題が挙げられる. 特に標的抗原の 発現特異性や使用する $\mathrm{T}$ cell 受容体の交差反応性は 副作用の観点から慎重に検討されるべきである ${ }^{12}$.

これに関しては現在, 各癌腫に含まれるユニークな 変異に由来する抗原を標的とする方針が打ち出され ている. Exome sequenceによる迅速な癌の全ゲノ ム解析技術と，ユニーク抗原に結合する $\mathrm{T}$ cell 受容 体遺伝子を効率よく単離する方法を組み合わせ, 臨 床応用に向けた研究開発が進められている99.

\section{III. 癌ワクチン療法}

ペプチド, リコンビナント蛋白, 樹状細胞, 修飾 自己癌細胞など様々な抗原を用いて実施されてきた が, 従来抗癌剤の効果判定基準である Response Evaluation Criteria in Solid Tumors (RECIST) ガイ ドラインによる効果判定でみたその効果は限られて いる13). しかしながら癌ワクチン療法は比較的簡便 で副作用が少ないため，多くの施設で多数の患者に 実施可能であるという点で優れている，その特性を 生かし, 多くの優れた基礎研究の結果をもとに, 切除後再発予防目的, あるいは他の治療々の併用療 法として, エンドポイントを progression free survival, Overall survival に置いた大規模試験が行われ ている.これらの結果をもって今後癌ワクチンの 真の有用性が判定されてゆくものと思われるが, ここでは癌ワクチンの有効性を表す最近の代表的な 報告をいくつか示す（表 1). まず，Sipuleucel-T は 2010 年に癌ワクチンとしては初めてアメリカ食品 医薬品局（FDA）に認可され話題になったホル モン療法不応性の進行期前立腺癌に対する癌ワク チンである14)。これは患者から採取した自己末梢 血単核球を, prostatic acid phosphatase (PAP) と granulocyte-macrophage colony-stimulating factor (GM-CSF) の融合蛋白で刺激したものを静脈内に 投与する細胞ワクチンである. 自己末梢血単核球に 含をれる抗原提示細胞がその効果を担うものと考え られている. 512 例を対象とした Phase III の臨床 試験では, プラセボ群 21.7 ケ月と比較して投与群 が 25.8 ケとわずかながら生存期間中央值の延長 を認めた。しかし奏効率でみると Sipuleucel-T 投与 群 341 例中わずか 1 例に部分寞解を認めたのみであ り, また血中 PSA が 50\%以下まで減少した症例の 比率も Sipuleucel-T 投与群全体の 2.6\%（プラセボ 群 1.3\%）という結果であるなど, 現状で十分な効 果があるとは言い難い。一方，多施設（21 施設） で行われた，185 例の進行期メラノーマを対象とし た Phase III のペプチドワクチン臨床試験では, 大 量 IL-2 単独投与群と, 大量 IL-2 に加えてメラノー マ抗原ペプチドを投与する (gp100 という色素細胞 特異的分化抗原に由来する CTL エピトープを 1 ア ミノ酸改変して HLA-A*0201 との親和性をあげた 人工ペプチド15)）群が比較された ${ }^{16)}$. その結果,

Overall survival の中央值は大量 IL-2 群で 11.1 ヶ月 であったのに対して peptide 併用群では 17.8 ヶ 
に延長し，RECIST による効果判定では奏効率は 6\%から 16\%に改善された. ワクチン単独の効果で はないものの明らかな上乗せ効果が認められてい る. また 20 名の HPV16 陽性の外陰上皮内腫瘍に 対して, HPV 由来 E6, E7 蛋白に由来する様々な Long peptide の混合を四肢の皮下に投与する臨床 試験では，外陰部腫瘍病変に対して奏効率 $60 \%$, $25 \%$ が完全寛解に至ったと報告されている ${ }^{17)}$.ごく 初期の病変に対する効果ではあるが，全身性に惹起 された HPV に対する免疫反応が高率に腫瘍拒絶を もたらしたという点で興味深い。これら以外にも現 在, 様々な癌を標的とした様々な方法による癌ワク チン療法の臨床試験が多数行われており, 大規模試 験での結果報告が待たれる.

\section{おわりに}

この総説では最近の癌免疫療法の臨床試験におい て良好な成果を報告しているものをいくつかを紹介 した．少ないながら劇的に奏効した症例からは，方 法によっては癌を免疫で制御しうる可能性が強く示 唆される.しかしながらどのプロトコルにおいても 現状でその恩恵を享受出来るのはごく一部の患者で ある.より多くのがん患者に簡便に施行でき，より 安定した高い効果を得られるように改善してゆくの が共通の課題と思われる. 平行して行う基礎研究に より，免疫療法が著効した患者の特性を無効例との 比較において解明すること, 各プロトコルへの適正 を判断するためのバイオマーカーを明らかにして個 別化すべき部分は個別化すること，などにより更な る発展が期待出来ると考える.

\section{文献}

1) Pardoll, D.M. : The blockade of immune checkpoints in cancer immunotherapy. Nat Rev Cancer 12 : 252-264, 2012.

2) Hodi, F.S. et al. : Improved survival with ipilimumab in patients with metastatic melanoma. N Engl J Med 363 : 711-723, 2010.

3) Robert, C. et al. : Ipilimumab plus dacarbazine for previously untreated metastatic melanoma. N Engl J Med 364 : 2517-2526, 2011.

4) Prieto, P.A. et al. : CTLA-4 blockade with ipilimumab : long-term follow-up of 177 patients with metastatic melanoma. Clin Cancer
Res 18 : 2039-2047, 2012.

5) Topalian, S.L. et al. : Safety, activity, and immune correlates of anti-PD-1 antibody in cancer. N Engl J Med 366 : 2443-2454, 2012.

6) Brahmer, J.R. et al. : Safety and activity of anti-PD-L1 antibody in patients with advanced cancer. N Engl J Med 366 : 2455-2465, 2012.

7) Rosenberg, S.A. : Development of effective immunotherapy for the treatment of patients with cancer. J Am Coll Surg 198 : 685-696, 2004.

8) Rosenberg, S.A. \& Dudley, M.E. : Adoptive cell therapy for the treatment of patients with metastatic melanoma. Curr Opin Immunol 21 : 233-240, 2009.

9) Restifo, N.P., Dudley, M.E. \& Rosenberg, S.A. : Adoptive immunotherapy for cancer: harnessing the $\mathrm{T}$ cell response. Nat Rev Immunol 12 : 269-281, 2012.

10) Robbins, P.F. et al. : Tumor regression in patients with metastatic synovial cell sarcoma and melanoma using genetically engineered lymphocytes reactive with NY-ESO-1. J Clin Oncol 29 : 917-924, 2011.

11) Inozume, $T$. et al. : Selection of CD8 + PD-1+ lymphocytes in fresh human melanomas enriches for tumor-reactive T cells. J Immunother 33 : 956-964, 2010.

12) Morgan, R.A. et al. : Cancer Regression and Neurological Toxicity Following Anti-MAGEA3 TCR Gene Therapy. J Immunother 36: 133-151, 2013.

13) Rosenberg, S.A., Yang, J.C. \& Restifo, N.P. : Cancer immunotherapy: moving beyond current vaccines. Nat Med 10 : 909-915, 2004.

14) Kantoff, P.W. et al. : Sipuleucel-T immunotherapy for castration-resistant prostate cancer. N Engl J Med 363 : 411-422, 2010.

15) Rosenberg, S.A. et al. : Immunologic and therapeutic evaluation of a synthetic peptide vaccine for the treatment of patients with metastatic melanoma. Nat Med $4: 321-327,1998$.

16) Schwartzentruber, D.J. et al. : gp100 peptide vaccine and interleukin-2 in patients with advanced melanoma. $N$ Engl J Med 364 : 21192127, 2011.

17) Kenter, G.G. et al. : Vaccination against HPV-16 oncoproteins for vulvar intraepithelial neoplasia. N Engl J Med 361 : 1838-1847, 2009. 